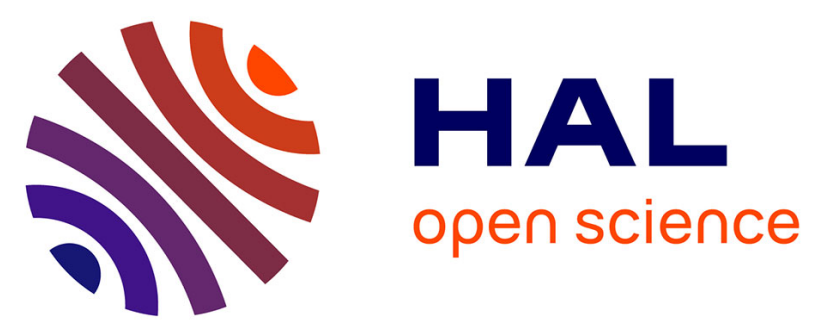

\title{
From the Middle-East Refuge to the Global Flight. Structural Organization of the Syrian Exodus between 2011 and 2016
}

David Lagarde, Ann Fournier, Le Ray

\section{- To cite this version:}

David Lagarde, Ann Fournier, Le Ray. From the Middle-East Refuge to the Global Flight. Structural Organization of the Syrian Exodus between 2011 and 2016. Revue Europeenne des Migrations Internationales, 2020, 35 (3-4), pp.267-297. 10.4000/remi.14757 . hal-03035528

HAL Id: hal-03035528

https://hal-univ-tlse2.archives-ouvertes.fr/hal-03035528

Submitted on 2 Dec 2020

HAL is a multi-disciplinary open access archive for the deposit and dissemination of scientific research documents, whether they are published or not. The documents may come from teaching and research institutions in France or abroad, or from public or private research centers.
L'archive ouverte pluridisciplinaire HAL, est destinée au dépôt et à la diffusion de documents scientifiques de niveau recherche, publiés ou non, émanant des établissements d'enseignement et de recherche français ou étrangers, des laboratoires publics ou privés. 


\section{From the Middle-East refuge to the global flight. Structural organization of the Syrian exodus between 2011 and 2016}

David Lagarde, Translator Ann Fournier Le Ray

In Revue européenne des migrations internationales Volume 35, Issue 3, July 2019, pages 267 to 297

ISSN 0765-0752

ISBN 9791090426658

This document is the English version of:

David Lagarde, Translator Ann Fournier Le Ray, «Du refuge moyen-oriental à la dispersion mondiale. Structuration de l'exode syrien entre 2011 et 2016», Revue européenne des migrations internationales 2019/3 (Vol. 35) , p. 267-297

\section{Available online at:}

https://www.cairn-int.info/journal-revue-europeenne-des-migrations-internationales-2019-3-page-267.htm

How to cite this article:

David Lagarde, Translator Ann Fournier Le Ray, «Du refuge moyen-oriental à la dispersion mondiale. Structuration de l'exode syrien entre 2011 et 2016», Revue européenne des migrations internationales 2019/3 (Vol. 35) , p. 267-297

Electronic distribution by Cairn on behalf of Université de Poitiers.

(C) Université de Poitiers. All rights reserved for all countries.

Reproducing this article (including by photocopying) is only authorized in accordance with the general terms and conditions of use for the website, or with the general terms and conditions of the license held by your institution, where applicable. Any other reproduction, in full or in part, or storage in a database, in any form and by any means whatsoever is strictly prohibited without the prior written consent of the publisher, except where permitted under French law. 


\section{From the Middle-East Refuge to the Global Flight. Structural Organization of the Syrian Exodus between 2011 and 2016}

Du refuge moyen-oriental à la dispersion mondiale. Structuration de l'exode syrien entre 2011 et 2016

Del refugio de Oriente Medio a la dispersión global. Estructuración del éxodo sirio entre 2011 y 2016

David Lagarde

Translator. Ann Fournier Le Ray

\section{(2) OpenEdition}

\section{Journals}

Electronic version

URL: http://journals.openedition.org/remi/14757

DOI: $10.4000 /$ remi. 14757

ISSN: $1777-5418$

\section{Publisher}

Université de Poitiers

\section{Printed version}

Date of publication: 1 December 2019

ISBN: 979-10-90426-65-8

ISSN: 0765-0752

Electronic distribution by Cairn

\section{CAIRN, INFO}

CHERCHER, REPÉRER, AVANCER

\section{Electronic reference}

David Lagarde, «From the Middle-East Refuge to the Global Flight. Structural Organization of the Syrian Exodus between 2011 and $2016 »$, Revue européenne des migrations internationales [Online], vol. 35 - n³ et 4 | 2019, Online since 01 January 2022, connection on 25 November 2020. URL : http:// journals.openedition.org/remi/14757 ; DOI : https://doi.org/10.4000/remi.14757

This text was automatically generated on 25 November 2020.

(c) Université de Poitiers 


\title{
From the Middle-East Refuge to the Global Flight. Structural Organization of the Syrian Exodus between 2011 and 2016
}

\author{
Du refuge moyen-oriental à la dispersion mondiale. Structuration de l'exode \\ syrien entre 2011 et 2016 \\ Del refugio de Oriente Medio a la dispersión global. Estructuración del éxodo \\ sirio entre 2011 y 2016
}

David Lagarde

Translation : Ann Fournier Le Ray

1 From the Armenian genocide and the longstanding Israeli-Palestinian crises over the second half of the twentieth century to the 2003 war in Iraq, the conflicts that have torn the Middle East have compelled millions to leave their country. In recent decades, along the constant flows of Palestinian refugees ${ }^{1}$ (Doraï, 2006) and those from Iraq (Chatelard and Dorai,, 2009), labor migrations within the region as well as from Southern Asia and, to a lesser extent from Eastern Europe and sub-Saharan Africa have contributed to the dynamics of mobility patterns across the Middle-East (Berthomière, 2002; De Bel-Air, 2005; Anteby-Yemini, 2008; Dahdah, 2014). As such, the region stands as a "migration crossroads" (Berthomière et al., 2003) which fully participates in the process of "the globalization of international migrations" (Berthomière, 2007). Since 2011, Syrian exiles have significantly fueled the machinery of this "migration geodynamics" (Simon, 1995), while restructuring the characteristics of the migration system in the Middle-East.

2 As a result of Bashar al-Assad regime's violent crackdown on the Syrian uprising, by the end of 2017, around 6.3 million people had fled outside Syria, while 6.8 million were said to be internally displaced. At the same time, Syrians stood for $32 \%$ of the 19.9 million international ${ }^{2}$ refugees registered by the United Nations High 
Commissioner for Refugees (UNHCR), which gives a clear idea of the sheer scale of the exodus and makes them the largest displaced population in the world.

3 As observed elsewhere in the world, concerning migration in the context of conflicts, the overwhelming majority of them - almost 5.3 million $^{3}$ - settled down in the four neighboring countries, thus changing the "demographic conditions" (Jaber, 2016) of these States. The exodus also concerned other areas, but much less so. Although the majority of exiles who left the Middle East moved to Europe, in December 2017, only 1 million people, asylum-seekers and refugees (i.e. granted the status before leaving) had been counted in the twenty-eight European countries. On the American continent, Canada and the United States were the main host countries, with respectively 54,000 and 33,000 people recorded by local authorities (Connor, 2018). Given the scale of these figures, this article aims at highlighting the factors (political and social and of security) likely to have influenced the pace, intensity and spatiality of Syrian flows towards the various settlement areas worldwide. In other words, chronicling their migration provides the appropriate distance to trace the structural development and the process of distribution of population movements since the beginning in spring 2011 until it roughly stabilized in the summer of 2016. It will also include a critical analysis of the way statistics are produced and used by national authorities and international institutions.

In order to provide a macro-political understanding of the Syrian exodus, this contribution relies on a set of reports and press articles repositioning the phenomenon in the changing fighting context in Syria and in the light of the political measures taken by transit and host countries to supervise refugee mobilities. This grey literature, mostly produced by humanitarian aid, was the starting point for a $\mathrm{PhD}$ thesis in geography based on a fully qualitative approach of the flows leaving Syria (Lagarde, 2018). I will therefore briefly use some of the testimonies collected in the course of that study to enhance my point. Between 2013 and 2016, for that PhD research, I conducted seventy-one semi-structured interviews with Syrian exiles. Most of the investigation was carried out in Jordan - which accounts for the focus on this particular country in this article - but I also interviewed refugees in Germany, France and, to a lesser extent, in Cairo and Oran. The choice of these various fieldworks was prompted by my desire to find out how refugees' personal networks had influenced their decision to leave, the choice of their settlement area but also the topography of their migration routes, their access to mobility and related resources - transport, money, information, accommodation. Following the "relationship threads" (Semin, 2009) of my interviewees, I was led to travel to the several places in the Euro-Mediterranean area which had played a central part in their movements and in those of their relatives.

5 By combining a global approach to flows with some ethnographic material prioritizing actors' point of view, this contribution means to underline that, despite the vision supported by some institutional bodies, refugees are not randomly distributed. It is also the case of so-called economic migrants (Massey et al., 1987; Ma Mung et al., 1998; Faret, 2003); even in the context of refugee migration, when their project is to be devised in emergency, it is absolutely necessary to focus on the spatiality of the exiles' social networks so as to understand how these relational structures affect the logics of the polarization of flows - particularly on cross-border scale - and the way they are connected to pre-conflict migration phenomena (Gehrig and Monsutti, 2003; Lagarde and Doraï, 2017). 


\section{Questioning Syrian Migration Numbers}

6 For the sake of data coherence, the numbers mentioned in this article are mostly those from UNHCR's online reports, particularly from Global Trends Forced Displacement in 2016. ${ }^{4}$ This document provides rather comprehensive statistics about the distribution per country of Syrian exiles in June 2016. Although methodological limitations and economic as well as political stakes actually impact migration statistics (Lessault and Beauchemin, 2009) - particularly when dealing with refugees (Crisp, 1999) researchers working on the Syrian exodus are regularly led to use statistics produced by UNHCR and by its partners. This article is no exception and relies on these data. It therefore proves necessary to question their methods of production and the strategies behind the organizations providing them.

\section{UNHCR's Production of Refugee Statistics}

7 Each year since 1994, the UNHCR bureau in charge of processing statistical information releases the UNHCR Statistical Yearbook, which provides the count of, asylum seekers, refugees, internal displaced and stateless persons recorded across the world. Since 2006, a report, entitled UNHCR Global Trends, gives access to detailed figures concerning these populations and to a digital database downloadable from a hypertext link. These statistics mostly come from population registration figures collected in the countries where the agency operates. Consequently, UNHCR is often led to improve its census and registration procedures. Since the beginning of the Syrian exodus, the efforts undertaken are particularly obvious in Jordan. As early as 2012, the Jordanian government together with UNHCR did open registration offices near the border and in the towns where most refugees had settled. In 2015, they launched a vast operation to control the identity of Syrians who benefitted from UNHCR's aid. The campaign served as an excuse for introducing some Orwellian-like technology enabling biometric authentication through an iris scan of all the recipients.

Data collected from the counting and authentication of the refugees' sociodemographic characteristics gave birth to considerable grey literature by the UN's agency and its partners. Some of it is available online on the site data.unhcr.org. This tool is presented as a portal devised to centralize the information required to improve humanitarian coordination and field operations; it enables anyone to download maps and databases related to the Syrian exodus. You may thus access countless statistics about the evolution of flows, their spatial distribution or even the age, sex and geographical origin of refugees from the Middle East. However, in light of the truly approximate nature of counting a population on the move, one is entitled to question the utility and relevance of releasing countless statistics based on such uncertain data.

\section{Uncertain Counting Can Make a Big Difference}

When seeking to obtain the most accurate numbers of refugees possible on the field, the interests of UNHCR and of its partners are manifold. The first goal is to be able to assess the size of the targeted population so as to adjust operations to the situation. These figures then help to determine the amount of staff required to deliver emergency 
aid, prepare budgets to finance field operations, or undertake fundraising. Needless to say, the financial interests underlying these humanitarian operations are significant. It is therefore essential to make the migration size visible as well as the extent of the operations to be conducted. This required visibility is one of the reasons for "the continuing policy of establishing refugee camps even in the face of much research suggesting that refugees and hosts may be better served by more flexible interventions which support local integration" (Bakewell, 1999: 2). Considering the number of humanitarian organizations operating in Jordan at the moment, this strategy towards increased visibility seems to be extremely successful (Tobin and Otis-Campbell, 2016).

10 However, in spite of the transparency displayed over the number of refugees actually welcomed in Jordan, some growing and significant inconsistency between UNHCR's figures and those claimed by the local government has gradually emerged. In November 2015, local authorities organized a census indicating that 1,265,514 Syrian citizens were in the country (De Bel-Air, 2016), against a little more than 630,000 registered by UNHCR for the same period. It is obvious that not all the Syrians in Jordan had registered with the UN's agency. Yet, all those who left the country via illegal migration networks often remained registered for several months. That is why the numbers claimed by local authorities seem largely overestimated.

11 In the course of the years 2000, the numbers of the Iraqi exile had already been disputed. Several researchers agreed that the numbers of refugees in Jordan (Chatelard, 2010 and 2011; Stevens, 2013) and in Syria (Doraï, 2009) had been greatly exaggerated by public authorities. By overestimating the Iraqi population on their territory, their goal was to call for donors' attention. Beside the amounts sent by migrants, international aid would have "contributed to the development of whole sectors of the Jordanian economy by providing start-up capital to Jordanian corporations and to major State-funded projects" (Chatelard, 2010: 2). Since 2007, the Jordanian government has for instance managed to rehabilitate pre-existing public schools thanks to donations from the United States Agency for International Development (USAID).

12 Local authorities maintained that donations would help to renovate establishments dedicated to accommodate a majority of exiles, which proved to be far from being the case (Seeley, 2010). Considering the numbers currently released, it looks as if Jordan authorities were trying to play the same game with the Syrian case; which, after all, seems only right when one considers the mechanisms initiated by Western governments to be able to negotiate that "countries in the Middle-East would recognize (in exchange of a few donations and UNHCR collaboration) [...] [exiles as] 'refugees', over there, and would accommodate them temporarily" (Agier, 2011: 54).

Because of the growing influence of private donors in the field of humanitarian aid, the dispute over refugee numbers is here to stay. Nevertheless, as it is not possible to access and confront data from different organizations, the following article will largely rely on UNHCR's statistics. Although not always reliable, their comprehensive coverage will outline the contours of the Syrian exodus as well as the process of the global dispersal affecting Syrian society since 2011. To ensure the chronological logics of this phenomenon, the article will first focus on flows between Syria and its neighboring countries. 


\section{Spatial-Temporal Dynamics of Syrian Refugee Flows in the Middle-East}

14 Since the early 1990s, the number of studies in social science dedicated to refugees has been steadily increasing (Black, 2001). One of the contributions of geography has been the identification of refugees' outgoing and ingoing areas, their reasons for leaving and the conditions and consequences of their settlement in the first host countries "in the South" and of their resettlement in the "North" (Black, 1991; Black and Robinson, 1993). This article follows in those studies, especially in that it envisages to draw up an inventory of the pace at which the Syrian population spread to various countries in the Middle-East, before questioning the modalities used to both manage borders and refugee arrivals in Jordan and, to a lesser extent, in Lebanon.

\section{1-2012: First Departures towards the Neighboring Countries}

On March 15 2011, following the North African and Yemeni uprising triggered by the Tunisian insurrection in December 2010, a few Deraa inhabitants started demonstrating. Three days later, a new march was organized in this town bordering Jordan. A few hours later, an elite unit was sent to put down the rebels and created the first two martyrs of the Syrian rebellion: Hossam Ayash and Mahmoud Jawabreh. ${ }^{5}$ In the early days of April, revolt spread to the other peripheral towns and villages kept out of the relative development of Damas and Alep town centers. As rebellion grew, the government's response remained the same as in Deraa: bullets facing the demonstrators' peaceful marches. By the end of April, crowds of refugees were moving along the Syrian borders. As seen in map 1, these flows of several thousand people from the vicinities of Idlib, Jisr al-Shoughour, Ma'arrat al-Numan and from the countryside around were going towards the Turkish province of Hatay where refugees were held in the Turkish Red Cross camps.

In the following months, these moves kept changing, many refugees would keep crossing the border back and forth, depending on how harsh repression was. ${ }^{6}$ Map 2 shows the direction of the main population movements observed from April to August 2011 between Syria and Lebanon, which also involved several thousand people mostly from Homs districts and from the villages of Tal Kalah, Rastan and Talbsieh, targeted by the government's violent repression. Unlike in Turkey, those people mostly found refuge with relatives already there in the district of Akkar. ${ }^{7}$ Some flows back to Syria, less numerous than departures, were also observed. As for Jordan, there was very little information concerning the first flows between the Deraa region and the vicinities of northern Jordan. Even more so than in Lebanon, historical connections (family and ethnic links) between the populations of the Hauran cross-border area greatly facilitated the settlement of refugees with their relatives living south of the border, which made the growing increase of the Syrian population in the north of the country invisible.

17 In July 2011, some of the opposition decided to take up arms to fight the government's atrocities and founded the Free Syrian Army (ASL). This led to increased fighting during the 2011-2012 winter and turned to the rebels' advantage, which drove the governmental army to intensify their attacks. While destruction was escalating at Idlib and everywhere in the surrounding region, fueling flows towards Turkey, in southern 
Syria, fighting in and around Deraa drove an ever- growing number of people to flee to Jordan.

Map 1: Evolution of flows as dictated by repression, between leaving for Turkey and going back to Syria. End of April 2011: first, refugee movements between Idlib governorate and Hatay province in Turkey

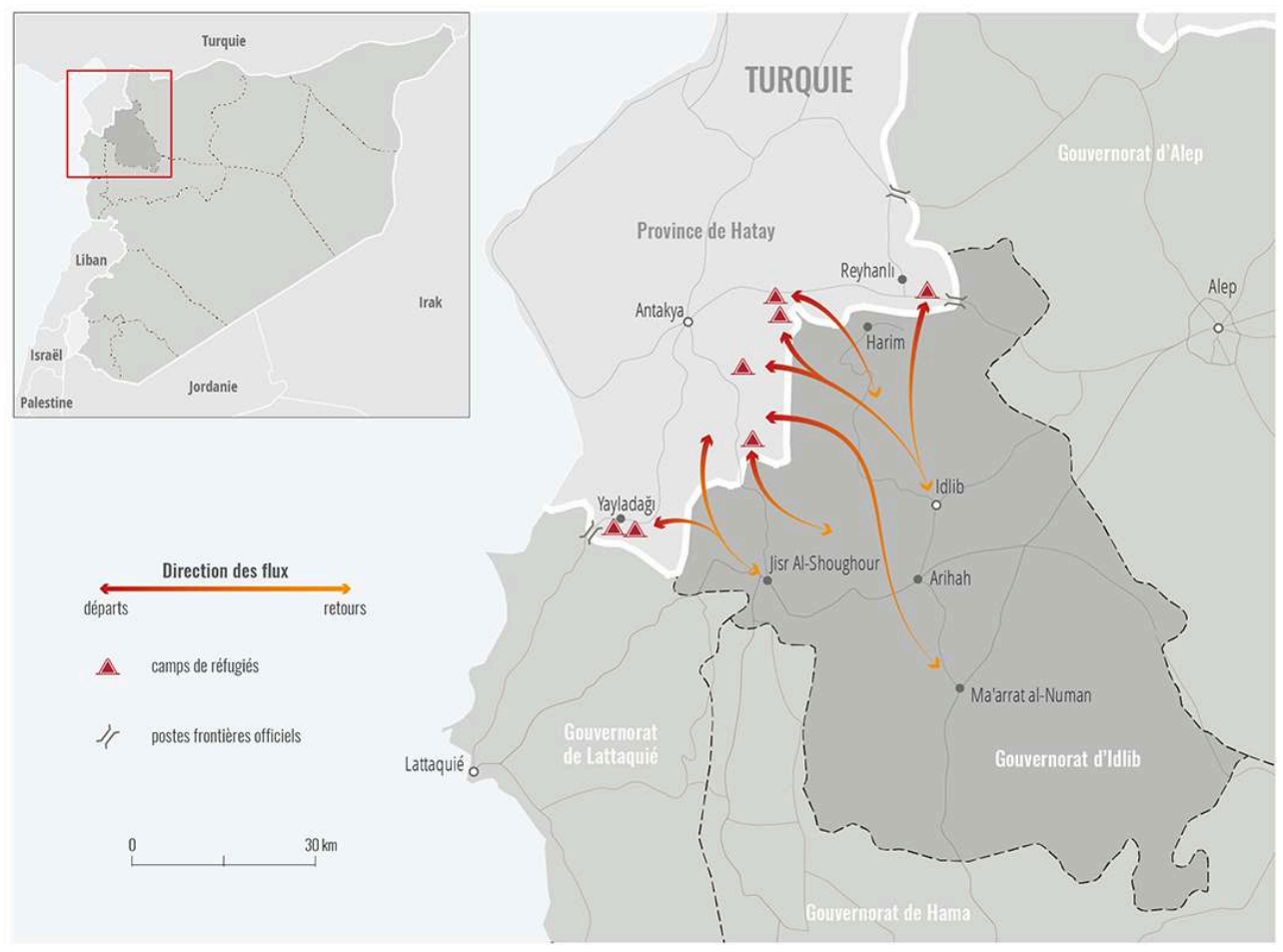

Sources: Natural Earth Data; Council of Europe (11/2011); The Atlantic (21/02/2012).

Credit: D. Lagarde, 2017. 
Map 2: Evolution of flows as dictated by repression, between leaving for Lebanon and going back to Syria. Mid--May 2011: first refugee movements between Homs governorship, in Syria, and North governorship, in Lebanon, where they settled within local communities in the Akkar district

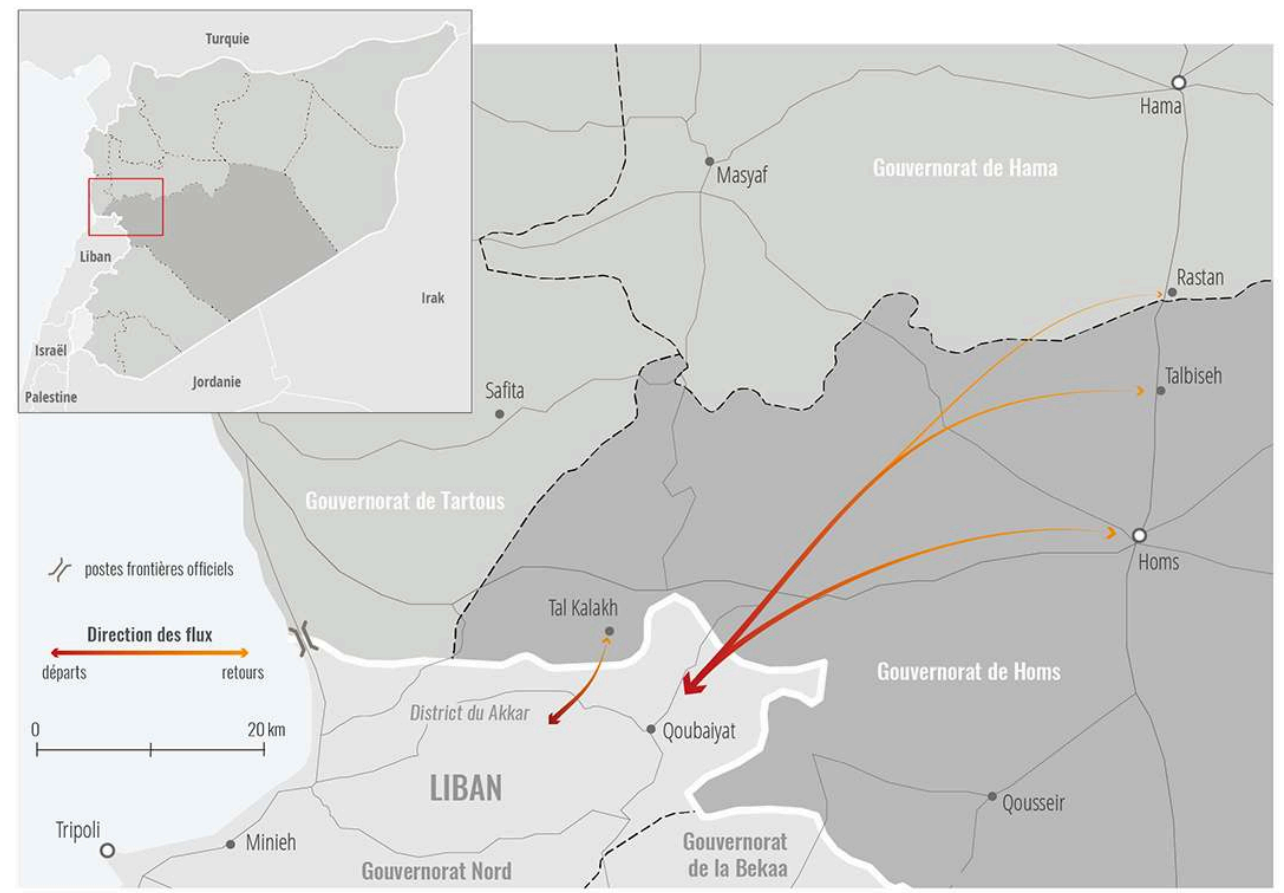

Sources: Natural Earth Data; International Medical Corps (07/2011)

Credit: D. Lagarde, 2017

In the central part of the country, the government launched a series of bombing raids on a scale not seen before in order to counter rebel progress in Homs. The intense fighting in this town of 1 million inhabitants prompted more and more people to flee to Lebanon, but, as conflict spread to a greater part of the country, a high number of Syrians were also displaced within their own country. In February, Talal, ${ }^{8}$ a forty-year old Syrian hurriedly left his flat in the district of Bab Dreb, in Homs, which flat was shattered to pieces by governmental bombings sometime after his departure. Being ASL supporters, Talal, his wife and their four children were welcomed by rebels in the village of Aïn M'neen, fifteen kms away from Damas. In return for their accommodation, Talal agreed to bring medicine to the hospitals where rebel fighters were treated. But, in July 2012, the governmental army targeted al-Tal, a neighboring vicinity of Aïn M'neen, which sent the family fleeing back to Damas in a hotel, where they could only stay three days before being compelled once more to flee.

\section{Summer 2012: Towards an Exponential Exodus}

The month of July 2012 was definitely a milestone in the evolution of the conflict. Damas and Alep town centers became the scene of violent clashes between the governmental army and the rebels. The sudden escalation led to an unprecedented number of departures since the beginning of the insurrection: over 100,000 people left the country during the months of July and August alone. At that time, Talal and his family decided to move to Jordan, where one of his cousins had been working as a real estate agent for almost twenty years. After leaving the country under cover to avoid being caught at the border, they were directed to the Zaatari camp by Jordanian 
authorities who had opened the camp by the end of July to meet the endless flow of rebels crossing the border away from official border posts. After spending one night at the camp, they were fetched by Talal's cousin and were able to leave legally thanks to his becoming their kafil. ${ }^{9}$

Farah, a nineteen-year old Syrian left the country at the end of August after the Syrian government had regained control of the district of Jobar, in Damas, where she used to live with her parents and six sisters and brothers. They found temporary refuge in Jordan, quite certain that the regime would collapse in a few weeks, a few months at most. Unlike Talal, they were not involved with the opposition, which enabled them to enter Jordan legally.

21 Nevertheless, they had first to pay a 100,000 SYP ${ }^{10}$ bribe to the Syrian border guards in charge of issuing the necessary authorizations to leave the country. Once in Jordan, they were free to continue towards Irbid. There, Farah's aunt, who was already living there with her Jordanian husband before the conflict, accommodated them for a month and a half until they could find a rental. Over the following months, the corruption of border guards working at the Nassib-Jaber official border post - regularly mentioned by the interviewees I met in Jordan - prompted a growing number of potential leavers to take ASL-controlled alternative routes which were mostly used by activists wanted by Syrian authorities and by people without proper travel documents.

Between August 2012 and June 2013, the confrontation deadlock led an additional 1.4 million refugees to register with UNHCR in the Middle East. During the summer 2013 , the total amount of refugees in the region had reached over 1.6 million people. Jordan and Lebanon were the first two host countries with over 490,000 refugees registered in each of the two States, before Turkey $(406,000)$, Iraq $(160,000)$ and Egypt $(70,000)$. In Jordan, the peak of arrivals was reached during the first five months of 2013. By then, almost 370,000 people had been registered in the country by UNHCR. At that time, people entered almost exclusively through the alternative crossing points along the western border in collaboration with the ASL. The heavy flows generated by these colossal movements led refugees to transit through a set of places where a number of various actors cooperated to help them to flee the country. As illustrated by map 3, these population movements networked a multiplicity of places along the Syrian-Jordanian border, which became the points of anchor in a cross-bordered, netted space, solely existing by and for the sake of the traffic. In those days, the ASL played a major role in operating this mobility system. Rebels used to be responsible for accompanying refugees in the last part of their travel, usually starting from freed-up districts in Deraa and from its neighboring villages. From there, groups would take whichever routes were available, depending on the evolution of the confrontation, to reach the unofficial crossing points west and south of Deraa, especially near Tal Shihab, al-Taibah and Heet (Roussel, 2015).

\section{Re-Routing towards Turkey after Jordanian and Lebanese Hardening}

23 In spring 2013, Jordan suddenly put an end to their policy of the "open door" to help Syrians seeking refuge. The authorities considered they had reached their maximum host capacity and decided to limit the number of new refugees. They ordered the ASL to 
stop organizing crossings along the western border and to create buffer zones to prevent would-be candidates from entering the Jordanian territory.

Map 3: Illegal crossings and refugee supervision along the Jordanian-Syrian border between 2011 and July 2013

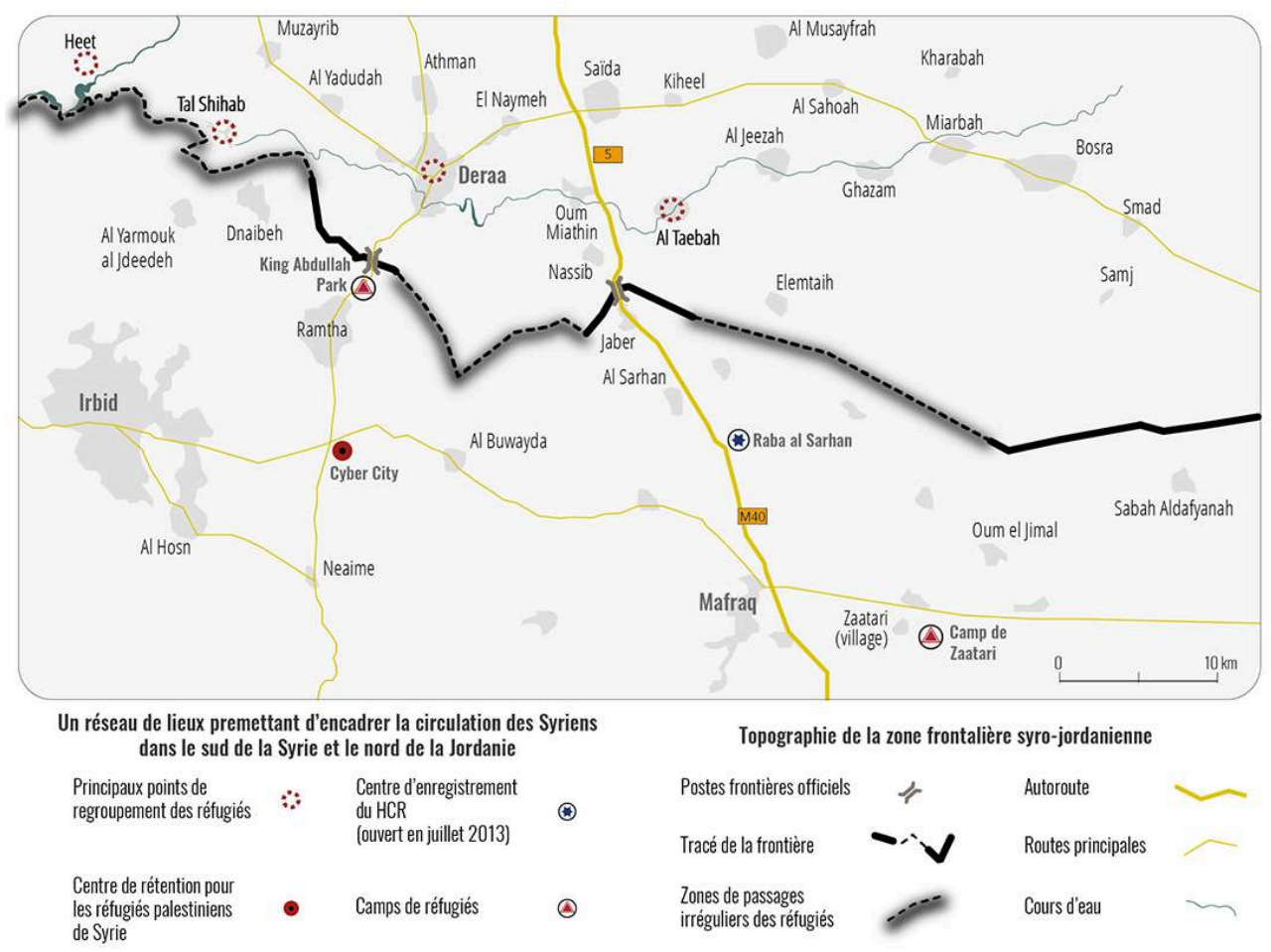

Sources: Google Maps; UNHCR

Credit: D. Lagarde, 2015.

The people wishing to enter Jordan then had to resort to the Bedouins and to their knowledge of the desert and, for a fee, they could be helped to reach the unofficial crossing points at Rukban and Hadalat, further east towards Iraq. In August 2013, the parents of Zacharia, a thirty-year old Syrian, fell victim to the new border lockdown. While they were trying to join their son in Amman, where he had been working as a "peddler" together with people from his village selling in Jordan since the 1980s (Lagarde, 2019), the border guards at Nassib-Jaber refused to let them in. With the unofficial crossing points on the western border being closed down, the only solution left to them was to reach Hadalat by relying on the Bedouins. But, due to the difficulty and risks of travelling by land for several days, part of it on foot and by night across desert areas controlled by the Syrian government, they gave up and decided to go back to their village, in the Barada valley, between Damas and the Lebanese border. A few days later, Zacharia's mother died tragically when their house partly collapsed, hit by governmental mortar fire.

In 2014, the relentless deterioration of safety in Syria and in Iraq forced the Jordanian government to further secure its eastern and northern borders (Ababsa, 2015). From July onwards, when the organization Islamic State (IS) seized the Iraqi town of Mosul, Jordanian authorities dramatically restricted entry via Rukban and Hadalat, under the excuse of terrorists infiltrating exiles. As only an average of a few dozen were allowed into Jordan, the displaced were then compelled to put up camps, made up of bits and 
pieces from whatever goods they had been able to bring while fleeing ${ }^{11}$. Once admitted in, the newcomers were directed to transit centers, controlled by Jordanian authorities and run by the International Committee of the Red Cross (ICRC), and, as can be seen on map 4, they were all located in desert areas, hardly accessible, including to humanitarian aid. According to an embassy senior civil servant interviewed in Amman in 2015, undocumented people, who had arrived in Jordan at the beginning of the confrontation, or men of fighting age living on their own were systematically driven back to Syria. As for refugees authorized to stay in the country, they were taken to the Azraq camp, opened in April 2014. Once registered there, they were entitled to legally leave the camp only after getting authorizations granted exceptionally in a discretionary way. As a result, the numbers of arrivals collapsed. Over a two-year period, from July2014 to June2016, only 55,000 new refugees were registered with UNHCR in Jordan.

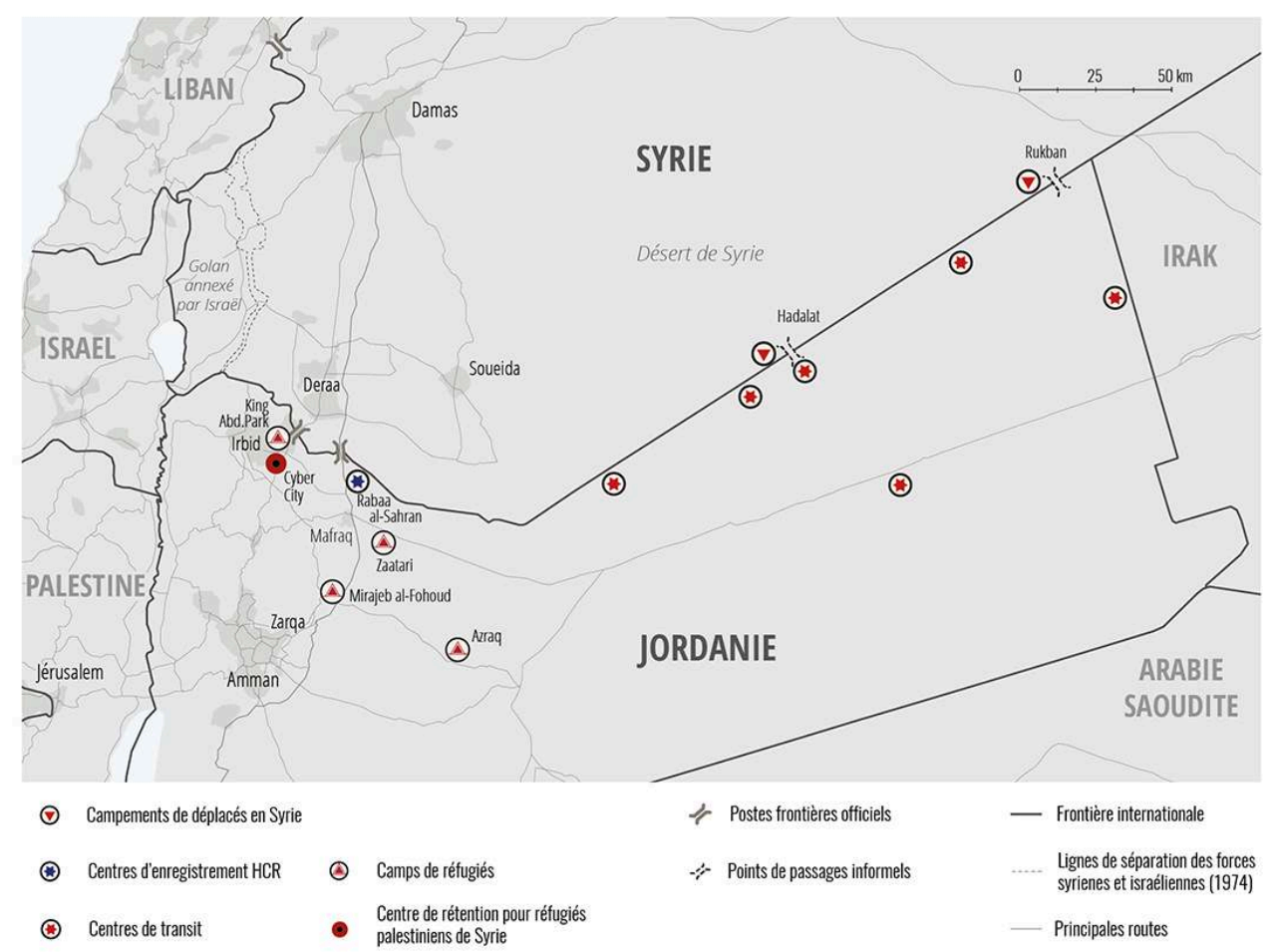

Map 4: Transit centers and Syrian refugee camps in North Jordan since 2014

Sources: ECHO (03/2016); Natural Earth Data.

Credit: D. Lagarde, 2017.

In Lebanon, according to the bilateral agreement signed with Syria in $1993^{12}$, no legal framework ruled entry and residence in the first years of the confrontation. "The strategy adopted during that period was called the 'no policy': 'no' to creating refugee camps, 'no' to an official closure of borders, "no" to evicting back to Syria" (Kabbanji, 2016: 106). This enabled many Syrians to continue circulating back and forth between the two countries working in Lebanon and visiting their family who had stayed in Syria. Nevertheless, while it used to be mostly male labor migration before the beginning of the crisis (Chalcraft, 2009), a growing number of these families with members already working in Lebanon started settling down there (Dahdah, 2018). In order to be granted some (small) material and financial subsidies, these families had to register with UNHCR (Drif, 2018). The UN's statistics for Lebanon mentioned around 1,120,000 
refugees residing in the country at the beginning of summer 2014, which approximately amounted to a quarter of the total number of inhabitants. Like in Jordan, the increasing flow of refugees was gradually met with greater and greater security measures in Lebanon. In 2014, the government introduced a series of measures for restricting Syrians' mobility. With a view to regulating flows, border policies got tougher, entry conditions stricter, while exiles were compelled to possess a residence permit which turned out to be more and more difficult to obtain but which was compulsory to reside legally in Lebanon. A work permit was also required to be employed in the building sector, concierge or cleaning services, but was only granted if you were sponsored by a Lebanese employer. These regulations dramatically impacted Syrians' entry into Lebanon and caused their number to plummet, especially from October 2014 (Kabbanji and Drapeau, 2017).

During the same period, the numbers of departures towards Turkey were, by contrast, as high as ever. While Russia, Iran and the Lebanese Hezbollah ensured the regime's military and economic survival and helped them to regain control of strategic locations on the national territory, several Islamic groups - made up of significant contingents of foreign fighters - were becoming a major party to the conflict. As the war became international, repression escalated and so did the fragmentation of the Syrian territory. To regain the areas under the control of opposition fighters, the army adopted a military strategy of dropping loads of bombs on civilian towns and villages until armed groups would leave them (Vignal, 2016). This murderous strategy - particularly targeting the eastern districts of Alep and other northern towns -, together with the expansion of the IS in the eastern part of the country and the simultaneous closure of Lebanese and Jordanian borders kept fueling flows towards Turkey. 
Map 5: June 2016, almost 5 million Syrians registered in Egypt, in Iraq, in Jordan, in Lebanon and in Turkey

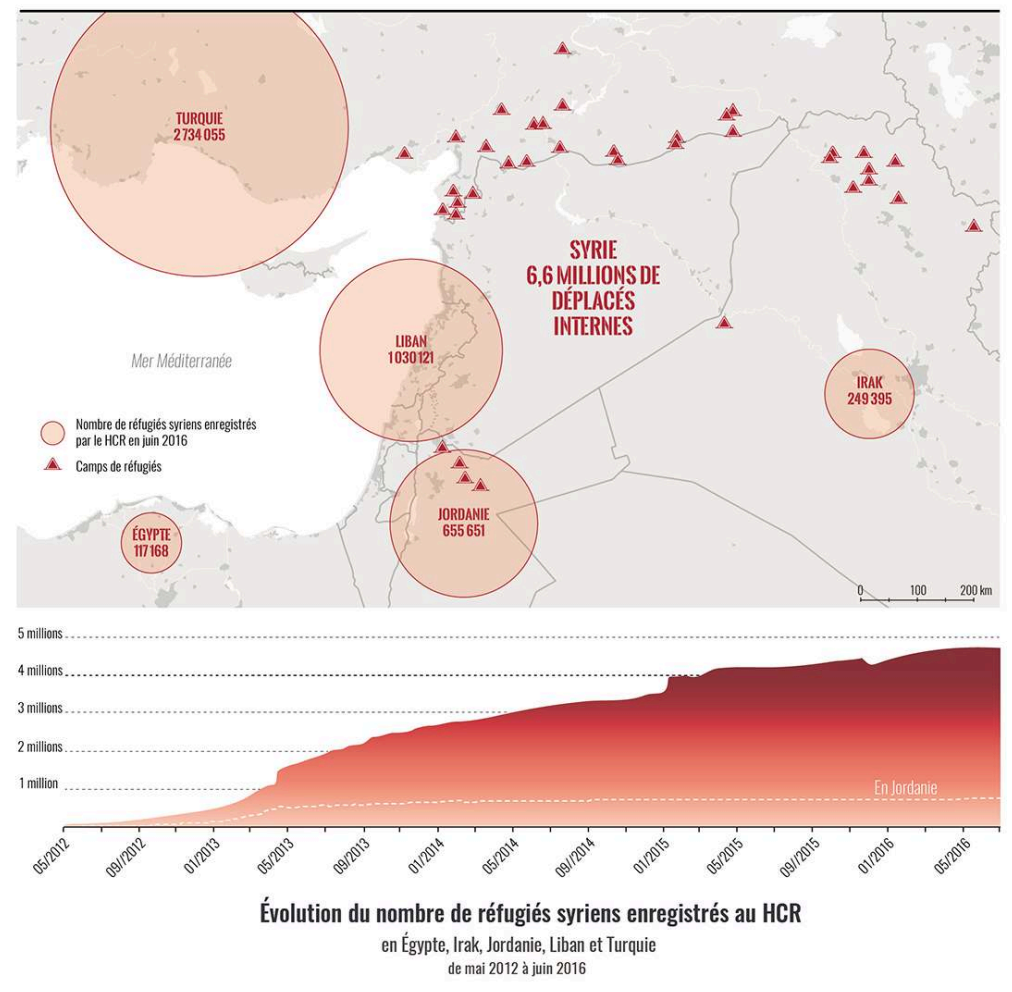

Sources: Natural Earth Data; UNHCR. Système de projection: Del ez Zor / Syria Lambert. Credit: D. Lagarde, 2017

Map 5 highlights the size and extent of the exodus in the five main host countries in the Middle East in June 2016. The number of Syrians registered at that time was close to 5 million people. Among these five countries, Turkey was clearly the one where the highest number of arrivals was recorded between the summer of 2013 and that of 2016. Arrivals slightly slowed down in Egypt and in Lebanon, but they did skyrocket in Turkey from about 400,000 people in summer 2013 up to over 2,7 million two years later! Concurrently, the great many difficulties faced by exiles in their first host countries led to a continuous increase in departures towards other destinations seen as more long-term solutions.

\section{Towards the Inevitable Dispersal of the Syrian Population}

Until the end of 2013, Syrians seeking refuge elsewhere and away from the Middle East were mostly better educated, highly qualified and socially privileged. Very much like what had been observed in the cross-border dynamics, the relation to migrants previously settled elsewhere in the rest of the world played a decisive part in these far away movements. Very much like what had been observed in previous decades concerning Palestinian refugees (Doraï, 2000) and Iraqis (Chatelard, 2002 and 2005), migration networks were set up between host countries and the rest of the world, particularly with Europe. Consequently, the following part of the article will broaden the observation to Syrian migration worldwide. The study will first focus on the factors 
behind these later departures, secondly, the analysis of the numbers of refugees who settled far from the Middle East will provide the required background to question the solidarity of the various host areas.

\section{As Refugees' Living Conditions Worsened, Departures for Western Destinations Increased}

had first been hosted in Syria's neighboring countries, extra regional movements clearly grew from 2014 onwards. As the confrontation continued to escalate and conditions of entry and residence in the neighboring countries got increasingly tougher, the scene was set for extra regional destinations. The factors behind these secondary movements greatly differed, depending on people's socio-economic profiles, the area they came from, but also on the settlement areas targeted abroad. However, some recurring reasons kept being mentioned by interviewees, such as the fear of police control and savings rapidly dwindling - leading to a significant decrease in purchasing power - often experienced as affecting their social status and which migrants attempted to face by taking proactive action.

31 In Jordan, the feeling of impoverishment and loss of confidence in the future greatly increased within the Syrian community in the course of 2014, when hundred thousand people who had settled outside the camps were denied access to a number of free healthcare public centers and no longer granted food stamps provided, so far, by the World Food Program (WFP). ${ }^{13}$ At the same time, there was a multiplication of controls of Syrian citizens working in the shadow economic sectors or who had left refugee camps without legal authorization. It kept jeopardizing their employment and circulation conditions, forcing them to live and work underground, under the constant fear of being sent back to Azraq or Zaatar camps, or, even worse, of being deported back to Syria if arrested..$^{14}$ In addition, problems of education were also mentioned by parents whose school kids or students found it difficult to get proper schooling or university education in the host country.

This whole set of constraints drove Mahmoud, a thirty-year old Syrian, to move on to Europe in autumn 2015. After working as a door-to-door salesman, increasing police controls and the arrest of some of his fellow-workers convinced him to work as a caretaker, a definitely safer but also far less paid job. As there were no real prospects of going back to Syria and because of the uncertainty for Syrians to obtain a legal status as refugees in Jordan, he and his wife decided to risk entering Germany illegally. They considered the country as the best place to start anew and, above all, the most likely to provide their two-year old daughter with better education opportunities. When Mahmoud informed his uncle of their project, the latter asked him to take with them his ten-year old son who had left the Azraq camp illegally and had been without schooling since his arrival in Jordan a few months earlier. Their choice of Germany was strongly influenced by the advice provided by relatives who had undertaken the journey before.

33 Some of the people I interviewed, with a higher social and professional capital, were able to reach other western destinations. It was the case of Jalal, a youth from Damas whom I met in Amman in 2013 and who emigrated the year after to Toronto, where he passed the Canadian baccalaureate, which he had been unable to take in Syria. There, 
he joined his mother, a company manager, already living in Canada with her second husband before the beginning of the insurrection. Malek, a twenty-eight-year-old Syrian interviewed in Cairo, took advantage of visa opportunities offered by Brazilian authorities and left for Sao Paulo, where he stayed with friends he had earlier met in Havana (Cuba) at the university where he was studying agronomy between 2005 and 2011. He had decided to leave mostly because of lack of security in General al-Sissi's Egypt.

Philippines, Bahrein, Kuwait, the United States, Singapore, Saudi Arabia, Finland, Algeria, Sweden, England, France, Greece or Belgium are some of the destinations mentioned by the people I met or whom I interviewed. As will be shown below, although only a small minority of Syrians were able to take these extra regional routes, these experiences nevertheless shape up the contours of a "migrating planet" (Simon, 2008) where the Syrian community decided to settle down for the long term.

\section{Syrian Exile: A Globalized Phenomenon}

Although the member States of the Gulf Cooperation Council had adopted a number of measures facilitating the entry and residence of Syrian citizens on their territories ${ }^{15}$ (de Bel-Air, 2015), statistics about the Syrian population are rather vague. As a matter of fact, the numbers of foreigners per nationality being considered as sensitive data by governments - hence almost impossible to obtain - it is very difficult to assess their numbers precisely. Map 6 highlights this approximate distribution, while demonstrating to what extent mapping, which is supposed to represent one and the same phenomenon, may produce a very different picture, depending on the data used. By mirroring UNHCR's figures - displayed as full circles - with those released by these host countries' authorities - symbolized by drafted circles - it becomes obvious that, depending on the countries and on the organizations doing the counting, population stocks may vary by several hundred thousand people, just like in Saudi Arabia!

In summer 2016, around 145,000 Syrian refugees were registered by UNHCR in North Africa, Egypt hosting $80 \%$ of them. The majority had arrived before July 2013, prompted by lower cost of living and easier entry thanks to the two countries' shared political pas $^{16}$. After the Egyptian army's takeover, arrivals rapidly dropped before resuming. It is still difficult to estimate the number of Syrians presently residing in Egypt. According to numbers released by UNHCR in June 2016, they were 117,000, whereas the government counted 300,000 of them and, according to NGOs, they amounted to as much as 500,000. At the same date in Libya, UNHCR was recording 20,000 refugees, which was a rather high number in light of the growing insecurity in the country since 2011. It can nevertheless be explained by the significant number of Syrians already working on the main Libyan labor markets before the insurrection. Several thousand exiles had also settled in Algeria and Morocco since 2011. There again, their conditions were facilitated by Syrians previously established there since the waves of nationalization in the 1960s. ${ }^{17}$ In Morocco, entrepreneurs - managing businesses in the catering sector, real estate or private education - greatly privileged recruiting these newly arrived exiles (Piaton, 2016). 
Map 6: Very approximate count of numbers of Syrians in the countries of the Gulf Cooperation Council

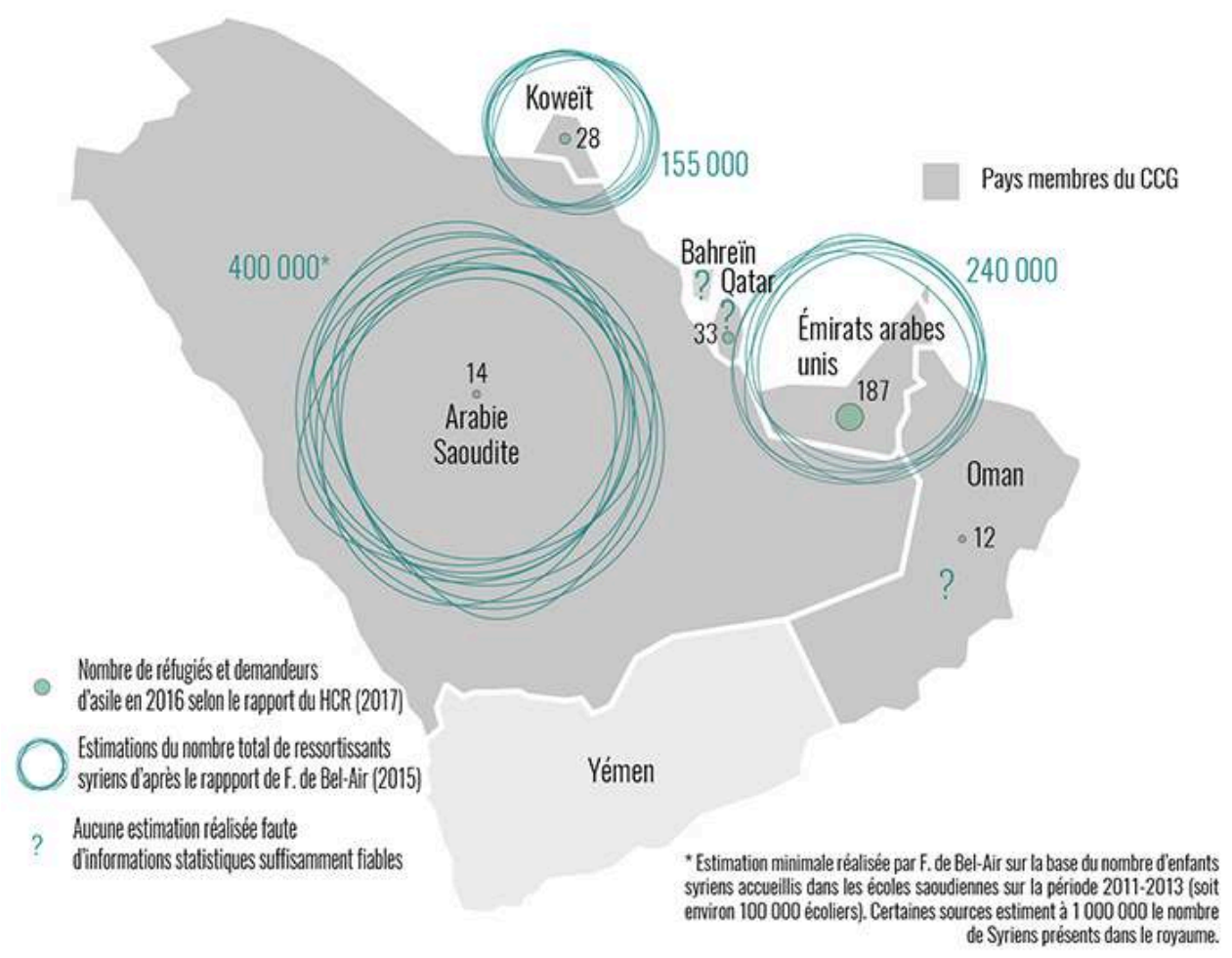

Sources: UNHCR (2017) Mid-Year Trends 2016; F. de Bel-Air (2015).

Credit: D. Lagarde

Since the end of the 1990s, the increasing closure of European external borders relentlessly drove asylum seekers to take more and more dangerous routes to reach the continent. Map 7, based on press articles published between 2014 and 2016, traces out the journeys of Syrians who tried to enter the European Union through very "tortuous" routes. If it can be said that the number of people who transited through Russia, Brazil or Comoros remained extremely limited, numbers crossing sub-Saharan Africa grew considerably. Some of them got stuck for lack of money and, by default, "chose" to settle down in countries which they had only originally seen as mere steps in their migration towards Europe. This "in-between" prompted the majority of them to remain invisible to local authorities and humanitarian aid organizations. That is why, although UNHCR only counted 391 Syrians in Mauritania in 2016, local organizations for refugees estimated that they were over 3,000 in Nouakchott alone. Five thousand kilometers further east, Sudan had become the first country of Syrian settlement in sub-Saharan Africa, with almost 5,000 refugees registered. But, according to local authorities, their number was certainly ten times higher, as statistics collected by a local NGO reported a population of 100,000 people. ${ }^{18}$

On the American continent, several countries in South America set up programs of settlement or alleviated visa requirements to facilitate the arrival of people displaced by the war in Syria. Despite a reception and integration policy seen as particularly liberal, only 4,000 Syrians benefitted from these measures in 2016. At that date, Brazil was the country with the highest number of exiles in the region. Most of them had obtained a humanitarian visa, granted to Syrians and Palestinians from Syria impacted 
by the war since 2013. Unlike what was being observed in the rest of the world, the organizations of the Syrian-Lebanese diaspora, established in Brazil since the end of the twentieth century (Truzzi, 2002), seem to have merely played a minor role in the reception process of the refugees who, as a consequence, turned to the Brazilian religious Sunni institutions for help (Baeza, 2018).

\section{Map 7: Roaming across the world with Europe on the horizon}

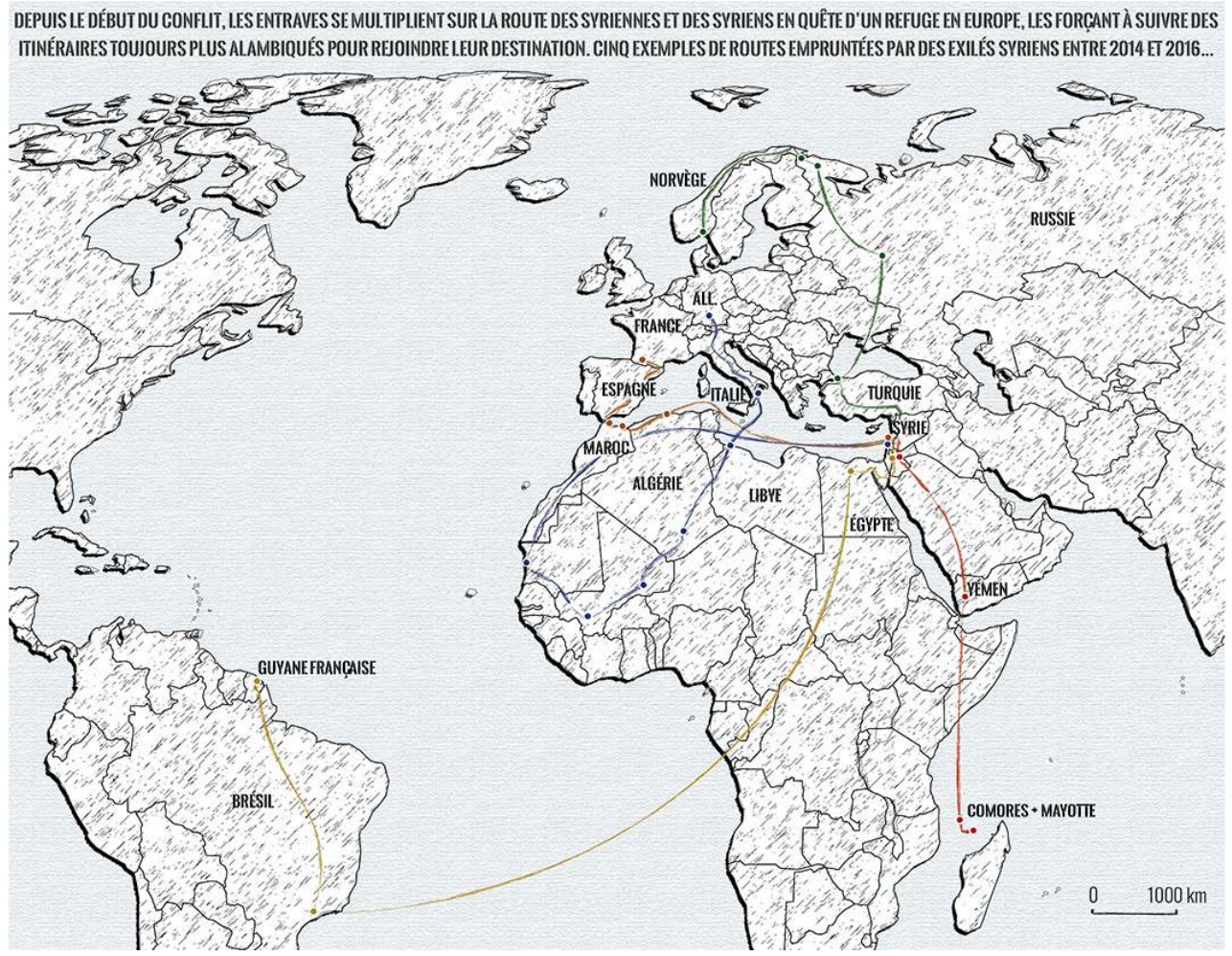

Sources: Comores-infos.net; irinnews.net; franceguyanne.fr; francetvinfo.fr; 20minutes.fr. Système de projection: Robinson.

Credit: D. Lagarde, 2018.

Further north, refugees hosted in Canada and in the United States also benefitted from settlement programs allowing those who had first fled to the Middle East and North Africa to legally reach these two destinations. The Obama administration was late in setting up these procedures, which accounts for Syrians' delayed and gradual arrival in the United States. Only 1,800 people had benefited from the program by the end of $2015^{19}$, but in June 2016, they were 9,000 to reside in the United States and as many as 33,000 by the end of 2017. In Canada, according to official local data, in spring 2016, over 25,000 Syrians had benefitted from the settlement campaign initiated in November 2015 by Justin Trudeau ${ }^{20}$. The number of recipients kept growing and reached 54,000 refugees by the end of 2017 (Connor, 2018).

\section{Europe: In-between Reception and Rejection}

During the last decades, the European Union has repeatedly and increasingly restricted third-party nationals' legal access to the Schengen area. The European migration policy took the form of externalization and increased border controls in order to block flows upstream by collaborating with neighboring States. The multiplication of migration 
barriers deprived an increasing number of asylum-seekers of entering the European territory to seek protection. Since the beginning of the conflict, the strategy of keeping foreigners at bay has enabled Europe to hold back the great majority of refugees into Syria's neighboring countries against significant financial contributions. While, at the end of 2013, over 2,560,000 Syrians had registered with UNHCR in Jordan, Lebanon, Turkey, Iraq and in Egypt, hardly 85,000 had applied for asylum in the European Union. ${ }^{21}$ Nevertheless, in 2015, migration flows between the Middle East and Europe changed significantly, both in numbers and areas involved. To avoid the numerous controls operated between Greece and Turkey, the "first" Syrian exiles who attempted to reach the European territory using illegal networks favored the cheaper and less controlled route across Central Mediterranean rather than across the Balkans. From the Middle East, candidates to European destinations reached Libya, via Algeria and embarked on extremely hazardous sea crossings to the Italian coasts before reaching their final destination, mainly Sweden and Germany. But, since January 2015, Algerian authorities compelled Syrian nationals to obtain a visa to be allowed in. The new situation once again moved migration routes and "revived" the Balkan route previously used by exiles from Eastern Europe, the Middle East or Central Asia.

41 According to $\mathrm{IOM}^{22}$ statistics, over 1 million asylum-seekers and so-called economic migrants were said to enter Europe illegally in $2015,{ }^{23}$ as compared to hardly 200,000 in the course of the whole previous year. 850,000 are thought to have reached the European continent by crossing the eastern Mediterranean. That same year, the 360,000 Syrians who had applied for asylum, followed by Afghans $(178,200)$ and Iraqis $(121,500)$, were overrepresented among the 1.2 million applicants registered in the twenty-eight countries of the European Union. ${ }^{24}$ Among the 675,467 Syrian asylumseekers and refugees already granted the status who were registered in the twentyeight members States of the European Union in June 2016, Germany was far ahead among the most hoped-for destinations. 372,830 people were already residing on the German territory, ${ }^{25}$ making up $0.45 \%$ of the overall population of the country. ${ }^{26}$ Sweden came second and hosted 102,100 Syrian exiles. ${ }^{27}$ Since the 1980s, the two States had adopted political measures facilitating the arrival of Palestinians and Iraqis (Doraï, 2006). They consequently enjoy a positive image among the people who, in the Middle East, are still seeking a refuge for the long-term. As for Germany, its positive reputation clearly increased in August, when Merkel's government decided to put an end to removing asylum-seekers back to the member State of their first arrival as ruled by the Dublin Convention..$^{28}$ The German population's warm welcome also reinforced the positive image exiles had of the country. Finally, the continuous increase of numbers of Syrian nationals residing in Germany clearly influenced the choice of this European destination, in order to join relatives recently settled there, as shown by the instance of Mahmoud and family mentioned earlier.

42 Still focusing on mid-2016, the third European destination was Greece with a Syrian population of 41,366 people, which was obviously the result of the central position of the country on the migratory routes connecting the Middle East to Western Europe. In other words, apart from those who had actually decided to settle down in Greece, a large number of exiles had merely applied for asylum there before continuing their journey west, thereby distorting statistics in UNHCR's reports.

This is clearly shown in the evolution of the numbers of Syrian refugees in Greece one year later. As a matter of fact, in June 2017, according to UNHCR, their overall 
population only amounted to 22,417 people; this report implies that the UN's agency based its counts on flows rather than on population stocks. Among other European destinations, Austria counted 37,438 Syrian exiles in June 2016, the Netherlands came next with 29,199 people. At that date, France ranked ninth with 10,173 Syrian refugees and asylum-seekers, that is, $0.01 \%$ of the overall population of the country. According to the statistics released for June 2017, only an additional 1,141 Syrians were hosted in France the year after.

\section{Conclusion}

In 2011, there were about 21 million inhabitants in Syria. Seven years later, over 13 million people had been forced to leave their home to settle down elsewhere in the country or outside national borders. Some of the first international movements were of course observed in April 2011 towards Turkey, but migration only changed size during the winter of 2012, when fighting escalated; it grew exponentially until 2014 when it actually started decreasing only in Jordan and Lebanon when extremely coercive migration policies were implemented.

Dispersal, which was first regional, was largely shaped by the great number of regular pre-war cross-border movements. Refugees overwhelmingly did move to the neighboring countries where they knew they would be helped by their relatives already there or, at least, to these areas they were acquainted with because they had already worked there. First experienced as a temporary settlement, it gradually became a longterm perspective as safety conditions in Syria inevitably deteriorated and prevented displaced people from going back home. As early as 2014, the difficulties faced by Syrians who had settled down in these initial host countries - mostly the result of national strategies aiming to worsen refugee conditions - prompted an increasing number of them to move once more to find better living conditions for the long term elsewhere in the world, particularly in Germany. These secondary movements, most of them operated within pre-war existing illegal networks, were mostly structured around large cities in the Middle East, Amman, Beirut or Istanbul. Because reaching Europe was costly, it required both substantial economic resources and some consistent social capital, mostly to be found in major urban areas in the Middle East.

Mapping the contours of the Syrian exodus remains a risky task due to the statistical uncertainty around the numbers of refugees who have settled down abroad. These loose estimates first result from the questionable character of counting a population constantly on the move between 2011 and 2016. The approximate slowdown of flows in the last two years should nevertheless make it possible to produce a more specific short-term statistical and geographical picture than what is presently available. But, UNHCR's almost complete monopoly in terms of counting displaced populations, added to closely related political and financial issues - which often lead most host countries to inflate actual numbers of refugees residing on their territory - will nonetheless remain a significant limitation to the work of would-be researchers interested in studying these migration dynamics, a research avenue which should definitely be further explored in the future.

47 It is also worth underlining how difficult (not to say impossible) it is for institutions to precisely monitor mobilities generated by political violence and resulting economic crises. These particularly unstable situations generally tend to force exiles to 
constantly readjust their movement "tactics "to the changeable contexts and structural constraints, making it up as they go along. Some migrants choose to move on both sides of borders whereas some others are forced to settle down abroad for longer periods, even though they do not necessarily register with state institutions or humanitarian aid, which further blurs the statistical mapping of displaced populations. This is what gives the Middle East context its strong heuristic value.

Because the article relies on UN's online numbers of the volume and breakdown of the Syrian population in exile, it might be blamed for providing a condensed picture of the phenomenon. The same could be said of some of the maps displayed. And yet, here, the space dynamics can clearly be appreciated. Map 8 dramatically displays the blatant disparities in the reception of Syrian refugees across the globe. Despite recurring discourses by the European political and media spheres, the burden of the scattered Syrian population weighs almost exclusively on countries in the Middle East. In other words, just like pre-war internal Syrian migration dynamics, the current exodus is characterized by a great majority of cross-border movements, coupled, on the fringe, with some long-distance trajectories aiming at all the regions of the globe. Since 2011, the actual transformations of the migration field have not so much concerned its geographical contours as the sheer numerical scale of the population stock as well as long-term characteristics. Current political developments in Syria seem to feature the al-Assad clan's hold on power which is unlikely to encourage, in the short term, many Syrians to go back home. Conversely, it may well stimulate transnational exchanges between the different settlement areas of the Syrian exiles worldwide, thus reinforcing the process of the transformation of Syrian "society into a diaspora community", which had already started before the conflict and has further intensified ever since the beginning of the exodus.

Map 8: Syrian exiles across the world. In June 2016, over 5.5 million Syrians had fled across the world among whom 4.6 million in one of the four neighboring countries (Iraq, Jordan, Lebanon, Turkey)

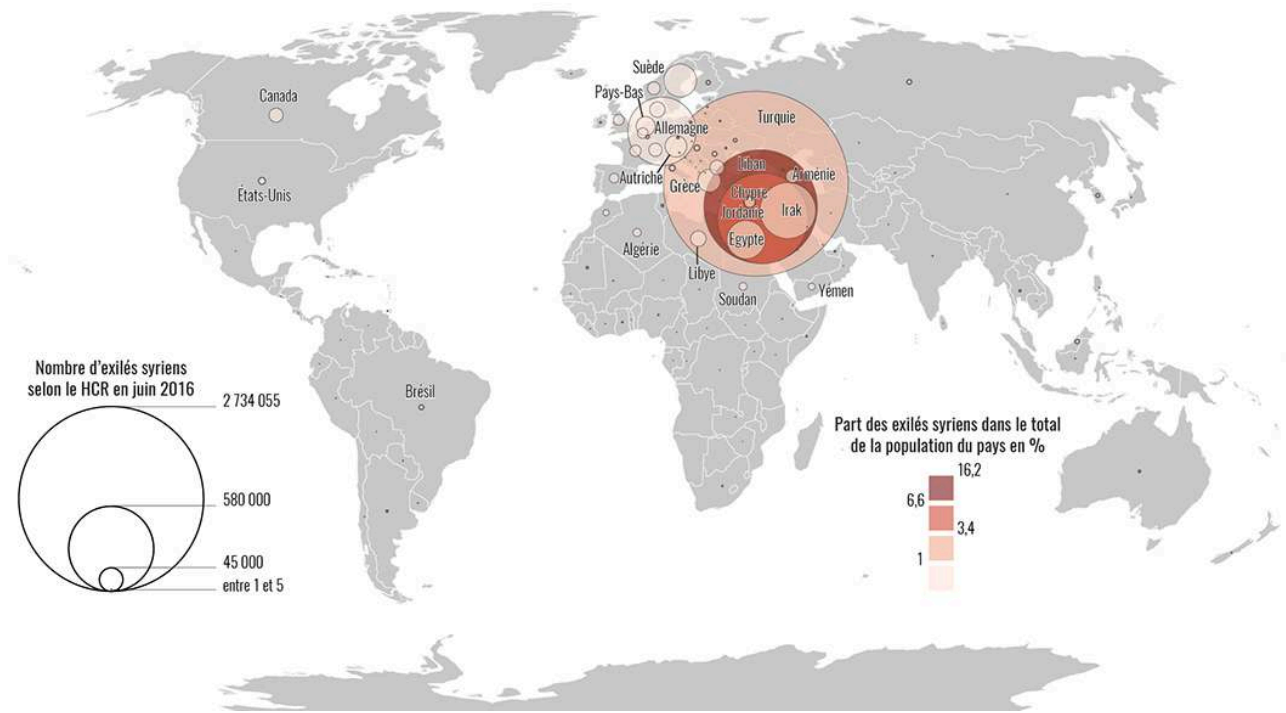

Sources: UNHCR (2017) Mid-Year Trends 2016; PopulationData.net. Système de projection: Robinson. Credit: D. Lagarde, 2018. 


\section{BIBLIOGRAPHY}

Ababsa Myriam (2015) De la crise humanitaire à la crise sécuritaire. Les dispositifs de contrôle des réfugiés syriens en Jordanie (2011-2015), Revue Européenne des Migrations Internationales, 31 (3-4), pp. 73-101.

Agier Michel (2011) Le couloir des exilés : Être étranger dans un monde commun, Bellecombe-enBauges, Éditions du Croquant, 117 p.

Anteby-Yemini Lisa (2008) Migrations africaines et nouveaux enjeux de la frontière israéloégyptienne, Cultures \& Conflits, 72, pp. 77-99.

Baeza Cecilia (2018) Le rôle des mosquées dans l'accueil des réfugiés syriens à São Paulo : entre confessionnalisation des solidarités et intégration à la société brésilienne, Brésil(s). Sciences humaines et sociales, 14, [en ligne]. URL : https://journals.openedition.org/bresils/3224

Bakewell Oliver (1999) Can we ever rely on refugee statistics?, Radical Statistics, 72, [online]. URL: https://www.radstats.org.uk/no072/article1.htm

Berthomière William (2007) Globalisation des migrations internationales, Revue des Mondes Musulmans et de la Méditerranée, 119-120, pp. 157-177.

Berthomière William (2002) Juifs ex-Soviétiques et Éthiopien : nouveaux acteurs de la mosaïque Israël, Hommes \& migrations, 1235, pp. 40-54.

Berthomière William, Doraï Mohamed Kamel et Tapia Stéphane (de) (2003) Éditorial. MoyenOrient : mutations récentes d'un carrefour migratoire, Revue Européenne des Migrations Internationales, 19 (3), pp. 7-8.

Black Richard (2001) Fifty Years of Refugee Studies: From Theory to Policy, International Migration Review, 35 (1), pp. 57-78.

Black Richard (1991) Refugees and displaced persons: geographical perspectives and research directions, Progress in Human Geography, 15 (3), pp. 281-298.

Black Richard and Robinson Vaughan (Eds.) (1993) Geography and refugees: patterns and processes of change, London-New York, Belhaven Press-Halsted Press, 220 p.

Bourgey André (1985) Importance des migrations internationales de travail dans l'Orient arabe, in André Bourgey, Philippe Gorokhoff, Michel Nancy, Alain Roussillon, Élisabeth Longuenesse et Salim Nasr Éds., Migrations et changements sociaux dans l'Orient arabe, Beyrouth, CERMOC, pp. 11-35.

Chalcraft John T. (2009) The invisible cage: Syrian migrant workers in Lebanon, Stanford, Stanford University Press, 310 p.

Chatelard Géraldine (2011) Iraqi Refugees and IDPs: From Humanitarian Intervention to Durable Solutions, Fondation pour la Recherche Stratégique, The Middle East Institute, p. 22.

Chatelard Géraldine (2010) Jordan: A Refugee Haven, Migration Information Source, [online]. URL: https://www.migrationpolicy.org/article/jordan-refugee-haven

Chatelard Géraldine (2005) Iraqi Asylum Migrants in Jordan: Conditions, Religious Networks and the Smuggling Process, in George Borjas and Jeff Crisp Eds., Poverty, International Migration and Asylum, London, Palgrave Mcmillan, pp. 341-370. 
Chatelard Géraldine (2002) Jordan as a transit country: semi-protectionist immigration policies and their effects on Iraqi forced migrants, Florence, Robert Schuman Centre for Advanced Studies (New Issues in Refugee Research).

Chatelard Géraldine et Doraï Mohamed Kamel (2009) La présence irakienne en Syrie et en Jordanie : dynamiques sociales et spatiales, et modes de gestion par les pays d'accueil, MaghrebMachrek, 199, pp. 43-60.

Connor Phillip (2018) Most displaced Syrians are in the Middle East, and about a million are in Europe, Pew Research Center, [online]. URL: https://www.pewresearch.org/fact-tank/2018/01/29/ where-displaced-syrians-have-resettled/

Crisp Jeff (1999) Who has counted the refugees? UNHCR and the politics of numbers, Policy Research Unit, UNHCR Working Papers n²12, [online]. URL: https://www.refworld.org/pdfid/4ff58e4b2.pdf

Dahdah Assaf (2018) The Experience of Labor Migration and Syrian Refugees' Strategies in Lebanon, in Mona Fawaz, Ahmad Gharbieh, Mona Harb and Dounia Salamé Eds., Refugees as City Makers, Issam Fares Institute for Public Policy and International Affairs (AUB), Beirut, Social Justice and the City Publication.

Dahdah Assaf (2014) Négocier sa place chez l'autre. Les migrants dans les espaces palestiniens à Beyrouth, Revue Européenne des Migrations Internationales, 30 (2), pp. 25-47.

De Bel-Air Françoise (2016) Migration profile : Jordan, Florence, CARIM.

De Bel-Air Françoise (2015) A Note on Syrian Refugees in the Gulf: Attempting to Assess Data and Policies, Gulf Research Center (Gulf Labour Markets and Migration), [online]. URL: https:// cadmus.eui.eu/handle/1814/37965

De Bel-Air Françoise (2005) Migration et politique. Politiques d'immigration de travail et construction nationale en Jordanie (1975-2002), in France Métral et Hana Jaber Éds., Mondes en mouvements. Migrants et migrations au Moyen-Orient au tournant du XXIe siècle, Beyrouth, Institut français du Proche-Orient, pp. 159-178.

Doraï Mohamed Kamel (2009) L'exil irakien à Damas. Modes d'insertion urbaine et reconfiguration des réseaux migratoires, EchoGéo, 8, [en ligne]. URL : https:// journals.openedition.org/echogeo/10976

Doraï Mohamed Kamel (2006) Les réfugiés palestiniens du Liban. Une géographie de l'exil, Paris, CNRS Éditions.

Doraï Mohamed Kamel (2000) Les parcours migratoires des Palestiniens de Suède et d'Europe du Nord, Revue d'études palestiniennes, 75 (23), pp. 38-52.

Drif Leila (2018) Les trajectoires de l'aide. L'accès des réfugiés syriens aux institutions d'assistance au Liban, in Assaf Dahdah et Nicolas Puig Éds., Exils syriens : parcours et ancrages (Liban, Turquie, Europe), Lyon, Le passager clandestin, pp. 29-42.

Faret Laurent (2003) Les territoires de la mobilité : migration et communautés transnationales entre le Mexique et les États-Unis, Paris, CNRS Éditions, 351 p.

Gehrig Tina et Monsutti Alessandro (2003) Territoires, flux et représentations de l'exil afghan : le cas des Hazaras et des Kaboulis, A contrario, 1 (1), pp. 61-78.

Jaber Hana (2016) Réfugiés syriens en Jordanie : choc démographique, résiliences et vulnérabilités, Confluences Méditerranée, 99, pp. 95-108. 
Kabbanji Lama (2016) Migration forcée et politiques migratoires. Le cas des réfugiés de Syrie au Liban, in Chris Beauchemin et Mathieu Ichou Éds., Au-delà de la crise des migrants : décentrer le regard, Paris, Karthala, pp. 97-116.

Kabbanji Lama et Drapeau Laurent (2017) Étudier les migrations de Syrie au Liban : propositions méthodologiques, Working Paper du Ceped, 36, 21 p.

Lagarde David (2019) Des colporteurs syriens dans la mondialisation, M@ppemonde, 126 [en ligne]. URL : http://journals.openedition.org/mappemonde/1363

Lagarde David (2018) Sur les routes de l'exil syrien. Récits de vie et parcours migratoires des réfugiés de Deir Mqaren, Thèse de doctorat, Université Toulouse 2 Jean-Jaurès.

Lagarde David et Doraï Mohamed Kamel (2017) De la campagne syrienne aux villes jordaniennes. Un réseau marchand transfrontalier à l'épreuve du conflit syrien, Espace populations sociétés. Space populations societies, 2, [en ligne]. URL : https://journals.openedition.org/eps/7212

Lessault David et Beauchemin Cris (2009) Ni invasion, ni exode. Regards statistiques sur les migrations d'Afrique subsaharienne, Revue Européenne des Migrations Internationales, 25 (1), pp. 163-194.

Ma Mung Emmanuel, Doraï Mohamed Kamel, Hily Marie-Antoinette et Loyer Frantz (1998) La circulation migratoire, bilan des travaux, Synthèse, Migrations études, 84, pp. 1-12.

Massey Douglas S., Alarcón Rafael, Durand Jorge and González Humberto (1987) The Social Organization of Migration, in Douglas S. Massey, Rafael Alarcón, Jorge Durand and Humberto González Eds., Return to Aztlan. The Social Process of International Migration from Western Mexico, University of California Press, pp. 139-171.

Piaton Alexandre (2016) Ethnographie des Syriens en exil à Rabat. Enjeux sociaux, économiques et politiques d'un cercle d'entraide, Mémoire de Master, EHESS.

Roussel Cyril (2015) La frontière syro-jordanienne dans le conflit syrien : enjeux sécuritaires, gestion frontalière, L'Espace Politique. Revue en ligne de géographie politique et de géopolitique, 27 (3), [en ligne]. URL : https://journals.openedition.org/espacepolitique/3658

Roussel Cyril (2003) Désenclavement et mondialisation : les réseaux migratoires familiaux des druzes du sud syrien, Revue Européenne des Migrations Internationales, 19 (3), pp. 263-283.

Seeley Nicholas (2010) The Politics of Aid to Iraqi Refugees in Jordan, Middle East Research and Information Project, 256, [online]. URL: https://merip.org/2010/09/the-politics-of-aid-to-iraqirefugees-in-jordan/

Semin Jeanne (2009) L'ethnologue dans les réseaux économiques des femmes migrantes : modes de présence simultanée entre la France et l'Afrique, Revue Européenne des Migrations Internationales, 25 (3), pp. 101-113.

Simon Gildas (2008) La planète migratoire dans la mondialisation, Paris, Armand Colin, 255 p.

Simon Gildas (1995) Géodynamique des migrations internationales dans le monde, Paris, Presses universitaires de France, $429 \mathrm{p}$.

Stevens Dallal (2013) Legal status, labelling, and protection: the case of Iraqi "refugees" in Jordan, International Journal of Refugee Law, 25 (1), p. 1.

Tobin Sarah A. and Otis Campbell Madeline (2016) NGO Governance and Syrian Refugee "Subjects" in Jordan, Middle East Research and Information Project, 278, [online]. URL: https:// merip.org/2016/04/ngo-governance-and-syrian-refugee-subjects-in-jordan/ 
Truzzi Oswaldo (2002) Libanais et Syriens au Brésil (1880-1950), Revue Européenne des Migrations Internationales, 18 (1), pp. 123-147.

Vignal Leila (2016) Syrie : la stratégie de la destruction, La vie des idées, [en ligne]. URL : https:// laviedesidees.fr/Syrie-la-strategie-de-la-destruction.html

\section{NOTES}

1. "Refugee" is here used in its generic sense to refer to people fleeing war troubles. The words "asylum-seeker", "statutory refugee" or simply "registered refugee" (with UNHCR) refer to the legal categories between which migrants often have to "wander" in the course of their migration. 2. This figure does not take into account the 5.4 million Palestinian refugees and their families under UNRWA mandate.

3. This figure, like all those mentioned concerning the countries in the Middle East, only refers to the number of Syrian nationals registered with UNHCR. Those who did not choose to be registered or who kept moving between Syria and the neighboring countries are not counted.

4. https://www.unhcr.org/statistics/unhcrstats/5943e8a34/global-trends-forceddisplacement-2016.html

5. For a comprehensive story of this episode of the insurrection, see Barthe Benjamin (2013) Les enfants de Deraa, l'étincelle de l'insurrection syrienne, Le Monde, 08/03/2013.

6. Council of Europe (2011) Syrian refugees on the Turkish border. Report on the visit to Ankara, [online]. URL: http://www.assembly.coe.int/CommitteeDocs/2011/amahlarg042011.pdf

7. International Medical Corps (2011) Psychological Assessment of Displaced Syrians at the LebaneseSyrian Northern Border, [online]. URL: https://data2.unhcr.org/fr/documents/download/36453

8. The names mentioned in the text have been changed to preserve the interviewees' anonymity.

9. Guarantor with the authorities.

10. About 1,200 euros.

11. As Syrian and Jordanian authorities prevented humanitarian organizations from entering Rukban and Hadalat camps, access to food, drinkable water and health care was extremely limited. Since they had been set up, these places spread endlessly to resemble huge slums where people were trying to survive in appalling conditions.

12. Syrian Palestinians were excluded from that agreement and ruled by a discriminatory legislative framework implemented in Lebanon in the 1990s.

13. These individual vouchers $(24 €)$ enabled people registered with UNHCR and legally residing in Jordan to buy basic food in groceries and supermarkets. Several refugees who had been deprived of vouchers in 2014were re-allocated this service and granted a payment card in 2015.

14. According to the Norwegian Refugee Council, in 2014, 8,500 Syrian refugees would have been forced into the Azraq camp. A report by Human Rights Watch deals with the more specific issue of deportations back to Syria. Cf. HRW (2017) I have no idea why they sent us back. Jordanian deportations and expulsions of Syrian Refugees, [online]. URL: https://www.hrw.org/report/ 2017/10/02/i-have-no-idea-why-they-sent-us-back/Jordanian-deportations-and-expulsionsSyrian

15. Measures specifically dedicated to relatives of Syrian workers already in the Gulf before the insurrection.

16. From 1958 to 1961, Syria and Egypt were regrouped within a single political entity: the United Arab Republic.

17. When the Baath party first came into office in Syria, they launched the nationalization of industrial and commercial companies, starting with private banking. 
18. Salih Zeinab Mohammed (2016) Shared language and religion in Sudan, IRIN, 31/05/2016, [online]. URL: https://www.irinnews.org/feature/2016/05/31/shared-language- and-religionSudan

19. Zong Jie and Batalova Jeanne (2017) Syrian Refugees in the United States, Migration Policy Institute, 12/01/2017, [online]. URL: http://www.migrationpolicy.org/article/syrian-refugeesunited-states

20. Government of Canada (2017) Welcome Refugees: Key Figures.

21. Many of these people were already legally living in Europe, with a work permit or a student visa, like several interviewees who had first come for university studies. Deterioration in Syria caused them to apply for asylum to be able to settle in the European Union for the long term.

22. IOM (2015) Irregular Migrant, Refugee Arrivals in Europe Top One Million in 2015, [online]. URL: https://www.iom.int/news/irregular-migrant-refugee-arrivals-europe-top-one-million-2015iom

23. Only $3 \%$ of them arrived through European land borders.

24. Eurostat (2016) Record number of over 1.2 million first time asylum seekers registered in 2015, [online]. URL: https://ec.europa.eu/eurostat/web/products-press-releases/-/3-04032016-AP

25. In June 2016, Germany welcomed a total of 1,052,127 statutory refugees and asylum-seekers. Beside Syrians, the most numerous nationalities were Afghans $(131,967)$ and Iraqis $(129,645)$.

26. The year after, UNHCR counted 540,085 Syrians in Germany. This State is the only one recording an increase in the number of Syrian exiles since June 2016.

27. They presently amount to almost 150,000 .

28. According to the convention, the State in charge of examining asylum applications is the first European country where the applicant entered and where he had to be sent back if stopped without legal documents or if trying to apply for asylum in another European country.

\section{ABSTRACTS}

By the end of 2017, nearly 6.3 million Syrian nationals had found refuge outside their country, leading to a rapid reconfiguration of the migration system in the Middle East. The scale of this globalized exodus raises questions about the spreading process of such a population displacement. By addressing this question from a macro-political approach, enriched by a cartographic illustration of the Syrian exodus, this article proposes to take an objective, neutral look at the spatial-temporal dynamics of this migration phenomenon, from its emergence in spring 2011 to its relative stabilization in 2016. It also aims to question the intensity and spatial dimension of these flows, in the evolving context of the confrontation in Syria and of the political orientations adopted by host States in the Middle East in terms of migration management, in particular by Jordan. The analysis implicitly highlights the inequitable reception of Syrian exiles worldwide.

À la fin de l'année 2017, près de 6,3 millions de ressortissants syriens avaient trouvé refuge hors de leur pays, engendrant par là même une rapide reconfiguration du système migratoire procheoriental. L'ampleur de cet exode mondialisé interroge le processus de diffusion d'un tel déplacement de population. En abordant cette question à partir d'une approche macro-politique, enrichie d'une lecture cartographique de l'exode syrien, cet article entend offrir un accès distancié sur les données et les dynamiques spatio-temporelles de ce phénomène, depuis son 
éclosion au printemps 2011, jusqu'à sa relative stabilisation en 2016. Il s'agira dès lors de questionner l'intensité et les spatialités de ces flux, dans le contexte évolutif des combats en Syrie et des orientations politiques adoptées par les États de premier accueil en matière de gestion migratoire, en particulier la Jordanie. Cette analyse souligne en filigrane l'inégalité de l'accueil des exilés syriens dans le monde.

Al final de 2017, casi 6,3 millones de sirios habían encontrado refugio fuera de su país, lo que condujo a una rápida reconfiguración del sistema de migración del Oriente Medio. La magnitud de este éxodo globalizado plantea interrogaciones sobre el proceso de expansión de este tipo de desplazamiento masivo Al abordar esta cuestión desde un enfoque macro político, enriquecido por una lectura cartográfica del éxodo sirio, este artículo pretende ofrecer un acceso distanciado a los datos y a la dinámica espacio-temporal de este fenómeno, desde su aparición en la primavera de 2011, hasta su relativa estabilización en 2016. El objetivo será, por tanto, cuestionar la intensidad y los aspectos espaciales de estos flujos migratorios en el contexto de la evolución de las violencias en Siria y de las orientaciones políticas adoptadas por los primeros Estados de acogida del Medio Oriente en materia de gestión de las migraciones, en particular Jordania. Este análisis pone de mostrar la desigualdad en la recepción de los exiliados sirios en el mundo.

\section{INDEX}

Mots-clés: conflit, réfugiés, flux migratoires, asile

Palabras claves: Siria, conflicto, refugiados, flujos migratorios, asilo

Geographical index: Syrie

Keywords: Syria, conflict, refugees, migration flows, asylum

\section{AUTHORS}

\section{DAVID LAGARDE}

Postdoctoral researcher CNRS - team LISST (UMR 5193), Associate member of the Institut français du Proche-Orient (UMIFRE 6 - MAEE/CNRS-USR 3135), Toulouse - Jean Jaurès University, Maison de la Recherche, 5 allées Antonio-Machado, 31058 Toulouse cedex 9; david.lagarde@univtoulouse.fr 